\title{
Significance of trace element quantities in the prostatic secretion of patients with benign prostatic hyperplasia and prostate cancer
}

\author{
Vladimir Zaichickํㅗ Sofia Zaichick ${ }^{2}$ \\ 'Radionuclide Diagnostics Department, Medical Radiological Research Centre, Obninsk 249036, Russia. \\ ${ }^{2}$ Laboratory of Dr. Gabriela Caraveo Piso, Feinberg School of Medicine, Northwestern University, Chicago, IL 60611, USA.
}

Correspondence to: Prof. Vladimir Zaichick, Radionuclide Diagnostics Department, Medical Radiological Research Centre, Korolyev St. 4, Obninsk 249036, Kaluga region, Russia. E-mail: vzaichick@gmail.com; vzaichik@outlook.com

How to cite this article: Zaichick V, Zaichick S. Significance of trace element quantities in the prostatic secretion of patients with benign prostatic hyperplasia and prostate cancer. J Cancer Metastasis Treat 2019;5:48.

http://dx.doi.org/10.20517/2394-4722.2019.07

Received: 10 Jan 2019 First Decision: 18 Mar 2019 Revised: 11 Apr 2019 Accepted: 14 May 2019 Published: 13 Jun 2019

Science Editor: Gopal Kundu Copy Editor: Cai-Hong Wang Production Editor: Jing Yu

\begin{abstract}
Aim: Benign prostatic hyperplasia and prostate cancer is an internationally important health problem of the man, particularly in developed countries. The aim of this exploratory study was to evaluate whether significant difference in the levels of $\mathrm{Zn}$ and some other trace elements of prostatic fluid exist between the inflamed and malignantly transformed prostate.
\end{abstract}

Methods: Prostatic fluid levels of $\mathrm{Br}, \mathrm{Fe}, \mathrm{Rb}, \mathrm{Sr}$, and $\mathrm{Zn}$ were prospectively evaluated in 52 patients with benign prostatic hyperplasia and 24 patients with prostate cancer. Measurements were performed using ${ }^{109} \mathrm{Cd}$ radionuclideinduced energy dispersive $\mathrm{X}$-ray fluorescent microanalysis. Prostatic fluid samples were divided into two portions. One was used for cytological study to exclude prostatitis, while the other was intended for trace element analysis.

Results: Mean values \pm standard error of means for concentration $(\mathrm{mg} / \mathrm{L})$ of trace element in the prostatic fluid of hyperplastic prostate were: $\mathrm{Br} 2.32 \pm 0.30, \mathrm{Fe} 11.5 \pm 1.8, \mathrm{Rb} 1.70 \pm 0.23, \mathrm{Sr} 1.41 \pm 0.26$, and $\mathrm{Zn} 488 \pm 42$. The contents of $\mathrm{Rb}$ and $\mathrm{Zn}$ were significantly lower (approximately 3.2 and 7.7 times, respectively) in fluid of cancerous prostate compared with those in fluid of hyperplastic prostate.

Conclusion: There are significant differences in trace element contents in the fluid of hyperplastic and malignantly transformed prostate. The great decrease in levels of $\mathrm{Rb}$ and $\mathrm{Zn}$ in the fluid of cancerous prostate might demonstrate

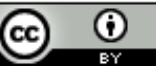

(C) The Author(s) 2019. Open Access This article is licensed under a Creative Commons Attribution 4.0 International License (https://creativecommons.org/licenses/by/4.0/), which permits unrestricted use, sharing, adaptation, distribution and reproduction in any medium or format, for any purpose, even commercially, as long as you give appropriate credit to the original author(s) and the source, provide a link to the Creative Commons license, and indicate if changes were made.

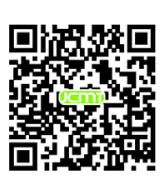


an involvement of these trace elements in etiology and pathogenesis of malignant prostate tumors. It was supposed that the differences in $\mathrm{Rb}$ and $\mathrm{Zn}$ levels in prostatic fluid can be used as tumor markers.

Keywords: Benign prostatic hyperplasia, prostate cancer, prostatic fluid, trace elements, energy-dispersive X-ray fluorescent analysis

\section{INTRODUCTION}

Prostate cancer ( $\mathrm{PCa})$ is the most prevalent nonskin male cancer in many populations, including USA, Scandinavia, West European states, Australia, New Zealand, and others ${ }^{[1,2]}$. Globally, PCa ranks second in incidence and the fifth in mortality in men, and represents a substantial public health burden ${ }^{[1,2]}$. Although the etiology of PCa is unknown, several risk factors including age and diet have been well identified. Thus, the risk of having PCa drastically increase with age, being three orders of magnitude higher for the age group 40-79 years than for those younger than 39 years $^{[3,4]}$. The odds of PCa diagnosis by age 79 years are one in six among countries with a high sociodemographic index.

Benign prostatic hyperplasia (BPH) is an internationally important health problem of the man, particularly in developed countries, and represents the most common urologic disease among of men after the age of fifty ${ }^{[4-7]}$. Incidence of histological BPH could be over $70 \%$ at 60 years old and over $90 \%$ at 70 years old ${ }^{[4,8]}$. To date, we still have no precise knowledge of the biochemical, cellular and molecular processes underlying the pathogenesis of $\mathrm{BPH}$. Although the influence of androgens and estrogens has been demonstrated, hormonal factors alone may not fully explain BPH development ${ }^{[9,10]}$.

Thus, the both PCa and BPH is the very common urologic disease in adult males. Moreover, use systematic review methods provide the statistical evidence that the association between PCa and BPH is significant ${ }^{[11,12]}$. $\mathrm{BPH}$ can be a cause of an elevated prostate specific antigen level in blood ${ }^{[13]}$. In these cases it is difficult to differentiate BPH from PCa because the findings of imaging modalities like TRUS and conventional MR Imaging can mimic those of PCa. Even biopsy doesn't play promising role in the diagnosis of BPH. As a result of this, BPH may be misdiagnosed as a malignant condition and end up in aggressive surgical management resulting in increased morbidity. This warrants the need of reliable diagnostic tool which has ability not only to diagnose BPH reliably but also to differentiate it from the PCa.

It was reported that the risk of having PCa and BPH depends on lifestyle and diet, including the intake of zinc $(\mathrm{Zn})$ and some other trace elements $(\mathrm{TE})^{[14-18]}$. TE have essential physiological functions such as maintenance and regulation of cell function, gene regulation, activation or inhibition of enzymatic reactions, and regulation of membrane function. Essential or toxic (mutagenic, carcinogenic) properties of TE depend on tissue-specific need or tolerance, respectively ${ }^{[19]}$. Excessive accumulation or an imbalance of the TE may disturb the cell functions and may result in cellular degeneration or death ${ }^{[19-24]}$.

In our previous studies a significant involvement of $\mathrm{Zn}$ and some other $\mathrm{TE}$ in the function of prostate was observed $^{[25-39]}$. Moreover, it was found that intracellular $\mathrm{Zn}$ and calcium $(\mathrm{Ca})$ excess is one of the main factors in the etiology of prostate cancer ${ }^{[16-18,24,25]}$. One of the main functions of prostate gland is a production of prostatic fluid ${ }^{[40]}$ with extremely high concentration of $\mathrm{Zn}$ and some other chemical elements. The first finding of remarkable high level of $\mathrm{Zn}$ concentration in human expressed prostatic fluid (EPF) was reported in the beginning of $1960 \mathrm{~s}^{[41]}$. Analyzing EPF expressed from prostate of 8 apparently healthy men aged 25-55 years it was found that $\mathrm{Zn}$ concentration varied in range from 300 to $730 \mathrm{mg} / \mathrm{L}$. After this finding several investigators have suggested that the measurement of $\mathrm{Zn}$ level in EPF may be useful as a marker of prostate secretory function ${ }^{[42,43]}$. It promoted a more detailed study of $\mathrm{Zn}$ concentration in EPF of healthy subjects and in those with different 
prostate diseases, including $\mathrm{PCa}^{[43,44]}$. A detailed review of these studies, reflecting the contradictions within accumulated data, was given in our earlier publication ${ }^{[44]}$.

In present study it was supposed by us that apart from $\mathrm{Zn}$ the levels of some other TE in EPF have to reflect a difference between possible functional suppression of hyperplastic prostate and functional disintegration of cancerous prostate. Thus, this work had four aims. The first one was to present the design of the method and apparatus for micro analysis of bromine $(\mathrm{Br})$, iron (Fe), rubidium (Rb), strontium $(\mathrm{Sr})$, and $\mathrm{Zn}$ in the EPF samples using energy dispersive X-ray fluorescence (EDXRF) with radionuclide source ${ }^{109} \mathrm{Cd}$. The second aim was to assess the $\mathrm{Br}, \mathrm{Fe}, \mathrm{Rb}, \mathrm{Sr}$, and $\mathrm{Zn}$ concentration in the EPF samples received from patients with $\mathrm{BPH}$ and $\mathrm{PCa}$. The third aim was to evaluate the quality of obtained results and to compare obtained results with published data. The last aim was to compare the concentration of $\mathrm{Br}, \mathrm{Fe}, \mathrm{Rb}, \mathrm{Sr}$, and $\mathrm{Zn}$ in EPF samples of hyperplastic and cancerous prostate gland.

\section{METHODS}

Specimens of EPF were obtained from 52 patients with BPH (mean age $63 \pm 6$ years, range 52-75 years) and from 24 patients with $\mathrm{PCa}$ (mean age $65 \pm 10$ years, range $47-77$ years) by qualified urologists in the Urological Department of the Medical Radiological Research Centre using standard rectal massage procedure. In all cases the diagnosis of BPH or PCa has been confirmed by clinical examination, including morphological results obtained during studies of biopsy and resected materials. Patients with BPH combined with chronic prostatitis or prostatic stones were excluded from the study. Subjects were asked to abstain from sexual intercourse for 3 days preceding the procedure. Specimens of EPF were obtained in sterile containers which were appropriately labeled. Twice $20 \mu \mathrm{L}$ of fluid were taken by micropipette from every specimen for trace element analysis, while the rest of the fluid was used for cytological and bacteriological investigations to exclude prostatitis. The chosen $20 \mu \mathrm{L}$ of the EPF was dropped on $11.3 \mathrm{~mm}$ diameter disk made of thin, ashfree filter papers fixed on the Scotch tape pieces and dried in an exsiccator at room temperature. Then the dried sample was covered with $4 \mu \mathrm{m}$ Dacron film and centrally pulled onto a Plexiglas cylindrical frame.

To determine concentration of the elements by comparison with a known standard, aliquots of solutions of commercial, chemically pure compounds were used for a device calibration ${ }^{[45]}$. The standard samples for calibration were prepared in the same way as the samples of prostate fluid. Because there were no available liquid Certified Reference Material (CRM) ten sub-samples of the powdery CRM IAEA H-4 (animal muscle) were analyzed to estimate the precision and accuracy of results. Every CRM sub-sample weighing about $3 \mathrm{mg}$ was applied to the piece of Scotch tape serving as an adhesive fixing backing. An acrylic stencil made in the form of a thin-walled cylinder with $11.3 \mathrm{~mm}$ inner diameter was used to apply the sub-sample to the Scotch tape. The polished-end acrylic pestle which is a constituent of the stencil set was used for uniform distribution of the sub-sample within the Scorch surface restricted by stencil inner diameter. When the sub-sample was slightly pressed to the Scotch adhesive sample, the stencil was removed. Then the sub-sample was covered with $4 \mu \mathrm{m}$ Dacron film. Before the sample was applied, pieces of Scotch tape and Dacron film were weighed using analytical balance. Those were again weighed together with the sample inside to determine the sub-sample mass precisely.

The facility for radionuclide-induced energy dispersive X-ray fluorescence included an annular ${ }^{109} \mathrm{Cd}$ source with an activity of $2.56 \mathrm{GBq}, \mathrm{Si}(\mathrm{Li})$ detector with electric cooler and portable multi-channel analyzer combined with a PC. Its resolution was $270 \mathrm{eV}$ at the $6.4 \mathrm{keV}$ line. The facility functioned as follows. Photons with the $22.1 \mathrm{keV}$ energy from ${ }^{109} \mathrm{Cd}$ source are sent to the surface of a specimen analyzed, where they excite the characteristic fluorescence radiation, inducing the $K_{\alpha} \mathrm{X}$-rays of trace elements. The fluorescence radiation got to the detector through a $10 \mathrm{~mm}$ diameter collimator to be recorded. 
Table 1. Energy dispersive X-ray fluorescence data of $\mathrm{Br}$, $\mathrm{Fe}, \mathrm{Rb}, \mathrm{Sr}$, and $\mathrm{Zn}$ contents in the IAEA H-4 (animal muscle) reference material compared to certified values $(\mathrm{mg} / \mathrm{kg}$, dry mass basis)

\begin{tabular}{lcccc}
\hline \multirow{2}{*}{ Element } & \multicolumn{3}{c}{ Certified values } & \multicolumn{1}{c}{ This work results } \\
\cline { 2 - 5 } & Mean & $\mathbf{9 5 \%} \mathbf{C l}$ & Type & Mean \pm SD \\
\hline $\mathrm{Fe}$ & 49 & $47-51$ & $\mathrm{C}$ & $48 \pm 9$ \\
$\mathrm{Zn}$ & 86 & $83-90$ & $\mathrm{C}$ & $90 \pm 5$ \\
$\mathrm{Br}$ & $3.5-4.7$ & $\mathrm{C}$ & $5.0 \pm 1.2$ \\
$\mathrm{Rb}$ & 4.1 & $17-20$ & $\mathrm{C}$ & $22 \pm 4$ \\
$\mathrm{Sr}$ & 18 & - & $\mathrm{N}$ & $<1$ \\
\hline
\end{tabular}

Mean: arithmetical mean; SD: standard deviation; C: certified values; N: non-certified values

Table 2. Some basic statistical parameters of $\mathrm{Br}, \mathrm{Fe}, \mathrm{Rb}, \mathrm{Sr}$, and $\mathrm{Zn}$ concentration $(\mathrm{mg} / \mathrm{L})$ in prostate fluid of patients with $\mathrm{BPH}$ and $\mathrm{PCa}$

\begin{tabular}{lccccccccc}
\hline Disease & Element & Mean & SD & SEM & Min & Max & Median & Per. 0.025 & Per. 0.975 \\
\hline $\mathrm{BPH}$ & $\mathrm{Br}$ & 2.32 & 1.84 & 0.30 & 0.230 & 8.70 & 1.62 & 0.268 & 5.84 \\
$52-75$ years & $\mathrm{Fe}$ & 11.5 & 10.8 & 1.8 & 1.06 & 54.1 & 9.31 & 1.09 & 38.9 \\
$n=52$ & $\mathrm{Rb}$ & 1.70 & 1.41 & 0.23 & 0.210 & 5.04 & 1.46 & 0.254 & 5.04 \\
& $\mathrm{Sr}$ & 1.41 & 1.09 & 0.26 & 0.230 & 4.79 & 1.12 & 0.300 & 4.02 \\
& $\mathrm{Zn}$ & 488 & 302 & 42 & 45.0 & 977 & 427 & 81.4 & 962 \\
$\mathrm{PCa}$ & $\mathrm{Br}$ & 4.51 & 7.19 & 2.27 & 0.697 & 24.3 & 2.08 & 0.704 & 20.4 \\
$47-77$ years & $\mathrm{Fe}$ & 21.7 & 28.8 & 8.7 & 7.70 & 107 & 13.9 & 7.70 & 86.8 \\
$n=24$ & $\mathrm{Rb}$ & 0.53 & 0.38 & 0.11 & 0.013 & 1.39 & 0.422 & 0.024 & 1.26 \\
& $\mathrm{Sr}$ & 1.70 & 2.15 & 0.76 & 0.230 & 6.83 & 0.872 & 0.275 & 5.95 \\
& $\mathrm{Zn}$ & 62.0 & 98.3 & 20.1 & 2.82 & 371 & 21.6 & 3.43 & 358 \\
\hline
\end{tabular}

M: arithmetic mean; SD: standard deviation; SEM: standard error of mean; Min: minimum value; Max: maximum value; Per. 0.025 percentile with 0.025 level; Per. 0.975: percentile with 0.975 level; DL: detection limit; BPH: Benign prostatic hyperplasia

The duration of the $\mathrm{Zn}$ concentration measurement was $10 \mathrm{~min}$. The duration of the $\mathrm{Zn}$ concentration measurement together with $\mathrm{Br}, \mathrm{Fe}, \mathrm{Rb}$, and $\mathrm{Sr}$ was $60 \mathrm{~min}$. The intensity of $K_{\alpha}$-line of $\mathrm{Br}, \mathrm{Fe}, \mathrm{Rb}, \mathrm{Sr}$, and $\mathrm{Zn}$ for EPF samples and standards was estimated on calculation basis of the total area of the corresponding photopeak in the spectra.

All EPF samples for EDXRF were prepared in duplicate and mean values of TE contents were used in final calculation. Using the Microsoft Office Excel programs, the summary of statistics, arithmetic mean, standard deviation, standard error of mean, minimum and maximum values, median, percentiles with 0.025 and 0.975 levels was calculated for TE concentrations in EPF of hyperplastic and cancerous prostate. The difference in the results between two groups of samples (BPH and $\mathrm{PCa}$ ) was evaluated by the parametric Student's $t$-test and non-parametric Wilcoxon-Mann-Whitney $U$-test.

\section{RESULTS}

Table 1 depicts our data for $\mathrm{Br}, \mathrm{Fe}, \mathrm{Rb}, \mathrm{Sr}$, and $\mathrm{Zn}$ mass fractions in ten sub-samples of CRM IAEA H-4 (animal muscle) and the certified values of this reference material. Of 4 ( $\mathrm{Br}, \mathrm{Fe}, \mathrm{Rb}$, and $\mathrm{Zn}$ ) TE with certified values for the CRM IAEA H-4 (animal muscle) we determined contents of all certified elements [Table 1]. Mean values $(\mathrm{M} \pm \mathrm{SD})$ for $\mathrm{Br}, \mathrm{Fe}, \mathrm{Rb}$, and $\mathrm{Zn}$ were in the range of $95 \%$ confidence interval. Good agreement of the TE contents analyzed by ${ }^{109} \mathrm{Cd}$ radionuclide-induced EDXRF with the certified data of CRM IAEA $\mathrm{H}-4$ [Table 1] indicate an acceptable accuracy of the results obtained in the study of the prostatic fluid presented in Tables 2-4.

Table 2 presents certain statistical parameters (arithmetic mean, standard deviation, standard error of mean, minimal and maximal values, median, percentiles with 0.025 and 0.975 levels) of the $\mathrm{Br}, \mathrm{Fe}, \mathrm{Rb}, \mathrm{Sr}$, and $\mathrm{Zn}$ concentrations in EPF of patients with BPH and PCa. 
Table 3. Median, minimum and maximum value of means of $\mathrm{Br}, \mathrm{Fe}, \mathrm{Rb}, \mathrm{Sr}$, and $\mathrm{Zn}$ concentration (mg/L) in prostate fluid of patients with $\mathrm{BPH}$ and $\mathrm{PCa}$ according to data from the literature

\begin{tabular}{|c|c|c|c|c|c|}
\hline \multirow[b]{2}{*}{ Disease } & \multirow[b]{2}{*}{ Element } & \multicolumn{3}{|c|}{ Published data [Ref.] } & \multirow{2}{*}{$\begin{array}{c}\text { This work results } \\
\qquad \mathbf{M} \pm \mathrm{SD}\end{array}$} \\
\hline & & $\begin{array}{c}\text { Median of means } \\
(n)^{\star}\end{array}$ & $\begin{array}{l}\text { Minimum of means } \\
M \text { or } M \pm S D_{1}(n)^{\star \star}\end{array}$ & $\begin{array}{l}\text { Maximum of means } \\
\left.\mathbf{M} \pm \mathrm{SD}_{\boldsymbol{r}}(\boldsymbol{n})\right)^{\star \star}\end{array}$ & \\
\hline \multirow[t]{5}{*}{$\mathrm{BPH}$} & $\mathrm{Br}$ & - & - & - & $2.32 \pm 1.84$ \\
\hline & $\mathrm{Fe}$ & - & - & - & $11.5 \pm 10.8$ \\
\hline & $\mathrm{Rb}$ & $2.35(1)$ & $2.35 \pm 1.85(11)^{[43]}$ & $2.35 \pm 1.85(11)^{[43]}$ & $1.70 \pm 1.41$ \\
\hline & $\mathrm{Sr}$ & - & - & - & $1.41 \pm 1.09$ \\
\hline & $\mathrm{Zn}$ & $459(7)$ & $268(7)^{[46]}$ & $9870 \pm 10130(11)^{[47]}$ & $488 \pm 302$ \\
\hline \multirow[t]{5}{*}{$\mathrm{PCa}$} & $\mathrm{Br}$ & - & - & - & $4.51 \pm 7.19$ \\
\hline & $\mathrm{Fe}$ & - & - & - & $21.7 \pm 28.8$ \\
\hline & $\mathrm{Rb}$ & $1.11(1)$ & $1.11 \pm 0.57(15)^{[43]}$ & $.1 .11 \pm 0.57(15)^{[43]}$ & $0.53 \pm 0.38$ \\
\hline & $\mathrm{Sr}$ & - & - & - & $1.70 \pm 2.15$ \\
\hline & $\mathrm{Zn}$ & $65.4(6)$ & $34.7 \pm 34.6(13)^{[44]}$ & $722(3)^{[49]}$ & $62.0 \pm 98.3$ \\
\hline
\end{tabular}

M: arithmetic mean; SD: standard deviation; $(n)^{\star}$ : number of all references; $(n)^{\star \star}$ : number of samples; BPH: Benign prostatic hyperplasia

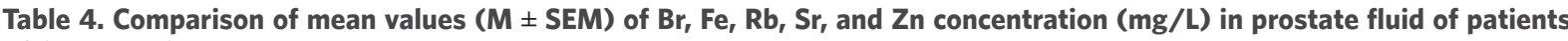
with $\mathrm{BPH}$ and $\mathrm{PCa}$

\begin{tabular}{|c|c|c|c|c|c|}
\hline \multirow{2}{*}{ Element } & \multicolumn{4}{|c|}{ Age groups } & \multirow{2}{*}{$\begin{array}{c}\text { Ratios } \\
\text { PCa to BPH }\end{array}$} \\
\hline & BPH & PCa & Student's $t$-test $\boldsymbol{P}$ value & $U$-test ${ }^{\star} P$ value & \\
\hline $\mathrm{Br}$ & $2.32 \pm 0.30$ & $4.51 \pm 2.27$ & $\leq 0.364$ & $>0.05$ & 1.94 \\
\hline $\mathrm{Fe}$ & $11.5 \pm 1.8$ & $21.7 \pm 8.7$ & $\leq 0.272$ & $>0.05$ & 1.89 \\
\hline $\mathrm{Rb}$ & $1.70 \pm 0.23$ & $0.53 \pm 0.11$ & $\leq 0.000024^{\#}$ & $<0.01^{\#}$ & 0.31 \\
\hline $\mathrm{Sr}$ & $1.41 \pm 0.26$ & $1.70 \pm 0.76$ & $\leq 0.729$ & $>0.05$ & 1.21 \\
\hline $\mathrm{Zn}$ & $488 \pm 42$ & $62.0 \pm 20.1$ & $\leq 0.00000001^{\#}$ & $<0.01^{\#}$ & 0.13 \\
\hline
\end{tabular}

\#significant difference $(P \leq 0.05)$. M: arithmetic mean; SEM: standard error of mean; *Wilcoxon: Mann Whitney U-test; BPH: Benign prostatic hyperplasia

The comparison of our results with published data for $\mathrm{Br}, \mathrm{Fe}, \mathrm{Rb}, \mathrm{Sr}$, and $\mathrm{Zn}$ concentrations in EPF of hyperplastic and cancerous prostate ${ }^{[41-44,46-50]}$ is shown in Table 3. A number of values for $\mathrm{Zn}$ concentrations in EPF were not expressed on a wet mass basis in the cited literature. Therefore, we calculated these values using the published data for water - $93.2 \%{ }^{[50]}$.

The ratios of means and the differences between mean values of $\mathrm{Br}, \mathrm{Fe}, \mathrm{Rb}, \mathrm{Sr}$, and $\mathrm{Zn}$ concentrations in EPF of patients with $\mathrm{BPH}$ and $\mathrm{PCa}$ are presented in Table 4.

\section{DISCUSSION}

The mean values and all selected statistical parameters were calculated for $5(\mathrm{Br}, \mathrm{Fe}, \mathrm{Rb}, \mathrm{Sr}$, and $\mathrm{Zn}) \mathrm{TE}$ concentrations [Table 2]. The concentrations of $\mathrm{Br}, \mathrm{Fe}, \mathrm{Rb}, \mathrm{Sr}$, and $\mathrm{Zn}$ were measured in all, or a major portion of EPF samples of hyperplastic and cancerous prostate.

The mean of $\mathrm{Zn}$ concentration obtained for BPH group of prostate fluid, as shown in Table 3, agrees well with median of means cited by other researches $\mathrm{s}^{[41-44,46-50]}$. The mean of Rb concentration obtained for EPF samples of CP group agrees well with our data reported 38 years ago ${ }^{[43]}$. No published data referring to $\mathrm{Br}$, $\mathrm{Fe}, \mathrm{Rb}$, and $\mathrm{Sr}$ concentrations in EPF samples of patients with $\mathrm{CP}$ were found.

In the EPF samples of cancerous prostate our results were comparable with published data for $\mathrm{Zn}$ concentrations [Table 3]. The mean of Rb concentration obtained for EPF samples of PCa group was some lower than our data reported 38 years ago ${ }^{[43]}$. No published data referring to $\mathrm{Br}$, $\mathrm{Fe}$, and $\mathrm{Sr}$ concentrations in EPF samples obtained from patients with PCa were found. 
From Table 4, it is observed that in EPF samples of PCa group the concentrations of Rb and $\mathrm{Zn}$ are 3.2 and 7.7 times, respectively, lower than levels of these trace elements in EPS of patients with BPH.

The range of means of $\mathrm{Zn}$ concentration reported in the literature for EPF of untreated hyperplastic prostate (from $268 \mathrm{mg} / \mathrm{L}$ to $9,870 \mathrm{mg} / \mathrm{L}$ ) and cancerous prostate (from 34.7 to $722 \mathrm{mg} / \mathrm{L}$ ) varies widely [Table 3]. This can be explained by a dependence of $\mathrm{Zn}$ content on many factors, including age, ethnicity, mass of the gland, presence of benign prostatic hyperplasia, and others. Not all these factors were strictly controlled in cited studies. Another and, in our opinion, leading cause of interobserver variability was insufficient quality control of results in these studies. In many reported papers EPF samples were dried at high temperature or acid digestion. Sample digestion is a critical step in elemental analysis and due to the risk of contamination and analytes loss contributes to the systematic uncontrolled analysis errors ${ }^{[51-53]}$. Thus, when using destructive analytical methods it is necessary to control for the losses of TE, for complete acid digestion of the sample, and for the contaminations by TE during sample decomposition, which needs adding some chemicals. It is possible to avoid these not easy procedures using non-destructive methods. Therefore, sample-nondestructive technique like ${ }^{109} \mathrm{Cd}$ radionuclide-induced EDXRF, which was developed and used by $\mathrm{us}^{[54,55]}$ is good alternatives for TE determination in EPF samples.

The ${ }^{109} \mathrm{Cd}$ radionuclide-induced EDXRF developed to determine TE concentrations in prostate fluid is micro method because sample volume $20 \mu \mathrm{L}$ (one drop) is quite enough for analysis. It is another advantage of the method. Amount of human prostatic fluid collected by massage of the normal prostate is usually in range $100-500 \mu \mathrm{L}^{[56]}$ but in a pathological state of gland, particularly after malignant transformation, this amount may be significantly lower. Therefore, the micro method of ${ }^{109} \mathrm{Cd}$ radionuclide-induced EDXRF developed to determine TE concentrations in prostate fluid is available for using in clinical studies.

Characteristically, elevated or deficient levels of TE and electrolytes observed in EPF of cancerous prostate are discussed in terms of their potential role in the initiation, promotion, or inhibition of prostate cancer. In our opinion, abnormal levels of TE in EPF of cancerous prostate could be the consequence of malignant transformation. Compared to other fluids of human body, the prostate secretion has higher levels of $\mathrm{Rb}$ and $\mathrm{Zn}$ and some other TE. These data suggests that these elements could be involved in functional features of prostate. The suppressed prostatic function can be both a cause and a consequence of BPH. However, malignant transformation is accompanied by a loss of tissue-specific functional features, which leads to a significant reduction in the contents of elements associated with functional characteristics of the human $\mathrm{EPF}(\mathrm{Rb}$ and $\mathrm{Zn})$.

Our findings show that concentration of $\mathrm{Rb}$ and $\mathrm{Zn}$ are significantly lower in EPF of cancerous prostate as compared to their concentrations in EPF of hyperplastic prostate [Table 4]. Thus, it is plausible to assume that levels of these trace elements in EPF can be used as tumor markers. However, this subjects needs in additional studies.

This study has several limitations. Firstly, analytical techniques employed in this study measure only five $\mathrm{TE}(\mathrm{Br}, \mathrm{Fe}, \mathrm{Rb}, \mathrm{Sr}$ and $\mathrm{Zn}$ ) concentrations in EPF. Future studies should be directed toward using other non-destructive analytical methods which will extend the list of TE investigated in EPF of hyperplastic and cancerous prostate. Secondly, the sample size of PCa group was relatively small. It was not allow us to carry out the investigations of TE contents in PCa group using differentials like histological types of tumors, stage of disease, and dietary habits of healthy persons and patients with PCa. Despite these limitations, this study provides evidence on cancer-specific $\mathrm{Rb}$ and $\mathrm{Zn}$ level alteration in EPF and shows the necessity the need to continue TE research of EPF in prostatic diseases.

In conclusion, in this work, TE measurements were carried out in the EPF samples of hyperplastic and malignant prostate using non-destructive instrumental EDXRF micro method developed by us. It was shown 
that this method is an adequate analytical tool for the non-destructive determination of $\mathrm{Br}, \mathrm{Fe}, \mathrm{Rb}, \mathrm{Sr}$, and $\mathrm{Zn}$ concentration in the EPF samples of human prostate. It was observed that in the EPF of cancerous prostate contents of $\mathrm{Rb}$ and $\mathrm{Zn}$ significantly lower in a comparison with those in the EPF of hyperplastic prostate. In our opinion, the decrease in levels of $\mathrm{Rb}$ and $\mathrm{Zn}$ in the EPF of cancerous prostate might demonstrate an involvement of these TE in etiology and pathogenesis of malignant prostate tumors. It was supposed that the changes of $\mathrm{Rb}$ and $\mathrm{Zn}$ levels in the EPF samples can be used as tumor markers.

\section{DECLARATIONS}

\section{Acknowledgments}

The authors are extremely grateful to Dr Tatyana Sviridova, Medical Radiological Research Center, Obninsk for supplying EPF samples.

\section{Authors' contributions}

Collected EPF samples, designed the EDXRF of samples, and carried out the statistical analysis of results: Zaichick $\mathrm{V}$

Managed the literature searches, wrote the first draft of the manuscript, and translated the manuscript into English: Zaichick S

Read and approved the final manuscript: Zaichick V, Zaichick S

\section{Availability of data and materials}

Not applicable.

\section{Financial support and sponsorship}

None.

\section{Conflicts of interest}

Both authors declared that there are no conflicts of interest.

\section{Ethical approval and consent to participate}

All studies were approved by the Ethical Committees of the Medical Radiological Research Centre, Obninsk. All procedures performed in studies involving human participants were in accordance with the ethical standards of the institutional and/or national research committee and with the 1964 Helsinki declaration and its later amendments or comparable ethical standards.

\section{Consent for publication}

Not applicable.

\section{Copyright}

(c) The Author(s) 2019.

\section{REFERENCES}

1. Rebbeck TR, Haas GP. Temporal trends and racial disparities in global prostate cancer prevalence. Can J Urol 2014;21:7496-506.

2. Wong MCS, Goggins WB, Wang HHX, Fung FDH, Leung C, et al. Global incidence and mortality for prostate cancer: analysis of temporal patterns and trends in 36 countries. Eur Urol 2016;70:862-74.

3. Rebbeck TR. Conquering cancer disparities: new opportunities for cancer epidemiology, biomarker, and prevention research. Cancer Epidemiol Biomarkers Prev 2006;15:1569-71.

4. Jemal A, Murray T, Samuels A, Ghafoor A, Ward E, et al. Cancer statistics, 2003. CA Cancer J Clin 2003;53:5-26.

5. Carter HB, Coffey DS. The prostate: an increasing medical problem. Prostate 1990;16:39-48.

6. Garraway WM, Collins GN, Lee RJ. High prevalence of benign prostatic hypertrophy in the community. Lancet 1991;338:469-71. 
7. Burnett AL, Wein AJ. Benign prostatic hyperplasia in primary care: what you need to know. J Urol 2006;175:S19-24.

8. Gong EM, Gerber GS. Saw palmetto and benign prostatic hyperplasia. Am J Chin Med 2004;32:331-8.

9. Lee KL, Peehl DM. Molecular and cellular pathogenesis of benign prostatic hyperplasia. J Urol 2004;172:1784-91.

10. Li W, Wu C-L, Febbo PG, Olumi AF. Stromally expressed c-jun regulates proliferation of prostate epithelial cells. Am J Pathol 2007;171:1189-98.

11. Alcaraz A, Hammerer P, Tubaro A, Schröder FH, Castro R. Is there evidence of a relationship between benign prostatic hyperplasia and prostate cancer? Findings of a literature review. Eur Urol 2009;55:864-73.

12. Dai X, Fang X, Ma Y, Xianyu J. Benign prostatic hyperplasia and the risk of prostate cancer and bladder cancer. A meta-analysis of observational studies. Medicine (Baltimore) 2016;95:e3493.

13. Guess HA. Benign Prostatic Hyperplasia and Prostate Cancer. Epidemiol Rev 2001;23:152-8.

14. Aslam R, Neubauer S. Dairy foods, milk, calcium, and risk of prostate cancer. Oncol Nutr Connect 2013;21:1,3-10.

15. Zaichick V, Zaichick S. Dietary intake of minerals and prostate cancer: insights into problem based on the chemical element contents in the prostate gland. J Aging Res Clin Practice 2015;4:164-71.

16. Zaichick V, Zaichick S, Wynchank S. Intracellular zinc excess as one of the main factors in the etiology of prostate cancer. J Anal Oncol 2016;5:124-31.

17. Zaichick V, Zaichick S, Rossmann M. Intracellular calcium excess as one of the main factors in the etiology of prostate cancer. AIMS Mol Sci 2016;3:635-47.

18. Tavani A, Longoni E, Bosetti C, Maso LD, Polesel J, et al. Intake of selected micronutrients and the risk of surgically treated benign prostatic hyperplasia: a case-control study from Italy. Eur Urol 2006;50:549-54.

19. Zaichick V. Medical elementology as a new scientific discipline. J Radioanal Nucl Chem 2006;269:303-9.

20. Ektessabi A, Shikine S, Kitamura N, Rokkum M, Johansson C. Distribution and chemical states of iron and chromium released from orthopedic implants into human tissues. X-Ray Spectrom 2001;30:44-8.

21. Yoshida S, Ektessabi A, Fujisawa S. XAFS spectroscopy of a single neuron from a patient with Parkinson's disease. J Synchrotron Radiat 2001;8:998-1000.

22. Isaacs JT. Prostatic structure and function in relation to the etiology of prostatic cancer. Prostate 1983;4:351-66.

23. Zaichick V, Zaichick S. Role of zinc in prostate cancerogenesis. In: Anke M, editors. Mengen und Spurenelemente, 19 Arbeitstagung. Jena: Friedrich-Schiller-Universität; 1999. pp. 104-15.

24. Zaichick V. INAA and EDXRF applications in the age dynamics assessment of Zn content and distribution in the normal human prostate. J Radioanal Nucl Chem 2004;262:229-34.

25. Zaichick S, Zaichick V. The Br, Fe, Rb, Sr, and $\mathrm{Zn}$ content and interrelation in intact and morphologic normal prostate tissue of adult men investigated by energy dispersive X-ray fluorescent analysis. X-Ray Spectrom 2011;40:464-9.

26. Zaichick $\mathrm{S}$, Zaichick V. INAA application in the age dynamics assessment of $\mathrm{Br}, \mathrm{Ca}, \mathrm{Cl}, \mathrm{K}, \mathrm{Mg}, \mathrm{Mn}$, and $\mathrm{Na}$ content in the normal human prostate. J Radioanal Nucl Chem 2011;288:197-202.

27. Zaichick V, Nosenko S, Moskvina I. The effect of age on 12 chemical element contents in intact prostate of adult men investigated by inductively coupled plasma atomic emission spectrometry. Biol Trace Elem Res 2012;147:49-58.

28. Zaichick V, Zaichick S. Age-related histological and zinc content changes in adult nonhyperplastic prostate glands. Age (Dordr) 2014;36:167-81.

29. Zaichick S, Zaichick V. The effect of age on $\mathrm{Ag}, \mathrm{Co}, \mathrm{Cr}, \mathrm{Fe}, \mathrm{Hg}, \mathrm{Sb}, \mathrm{Sc}, \mathrm{Se}$, and $\mathrm{Zn}$ contents in intact human prostate investigated by neutron activation analysis. Appl Radiat Isot 2011;69:827-33.

30. Zaichick $\mathrm{V}$, Zaichick $\mathrm{S}$. The effect of age on $\mathrm{Br}, \mathrm{Ca}, \mathrm{Cl}, \mathrm{K}, \mathrm{Mg}, \mathrm{Mn}$, and $\mathrm{Na}$ mass fraction in pediatric and young adult prostate glands investigated by neutron activation analysis. Appl Radiat Isot 2013;82:145-51.

31. Zaichick V, Zaichick S. INAA application in the assessment of Ag, $\mathrm{Co}, \mathrm{Cr}, \mathrm{Fe}, \mathrm{Hg}, \mathrm{Rb}, \mathrm{Sb}, \mathrm{Sc}, \mathrm{Se}$, and $\mathrm{Zn}$ mass fraction in pediatric and young adult prostate glands. J Radioanal Nucl Chem 2013;298:1559-66.

32. Zaichick V, Zaichick S. NAA-SLR and ICP-AES Application in the assessment of mass fraction of 19 chemical elements in pediatric and young adult prostate glands. Biol Trace Elem Res 2013;156:357-66.

33. Zaichick V, Zaichick S. Use of neutron activation analysis and inductively coupled plasma mass spectrometry for the determination of trace elements in pediatric and young adult prostate. Am J Analyt Chem 2013;4:696-706.

34. Zaichick V, Zaichick S. INAA application in the assessment of chemical element mass fractions in adult and geriatric prostate glands. Appl Radiat Isot 2014;90:62-73.

35. Zaichick V, Zaichick S. Determination of trace elements in adults and geriatric prostate combining neutron activation with inductively coupled plasma atomic emission spectrometry. Open J Biochem 2014;1:16-33.

36. Zaichick V, Zaichick S. Use of INAA and ICP-MS for the assessment of trace element mass fractions in adult and geriatric prostate. J Radioanal Nucl Chem 2014;301:383-97.

37. Zaichick $\mathrm{V}$. The variation with age of 67 macro- and microelement contents in nonhyperplastic prostate glands of adult and elderly males investigated by nuclear analytical and related methods. Biol Trace Elem Res 2015;168:44-60.

38. Zaichick V, Zaichick S. Androgen-dependent chemical elements of prostate gland. Androl Gynecol: Curr Res 2014;2:1-15.

39. Zaichick V, Zaichick S. Differences and relationships between morphometric parameters and zinc content in nonhyperplastic and hyperplastic prostate glands. Br J Med Med Res 2015;8:692-706.

40. Zaichick V. The prostatic urethra as a Venturi effect urine-jet pump to drain prostatic fluid. Med Hypotheses 2014;83:65-8.

41. Mackenzie AR, Hall T, Whitmore WF Jr. Zinc content of expressed human prostate fluid. Nature (London) 1962;193:72-3. 
42. Marmar JL, Katz S, Praiss DE, DeBenedictis TJ. Values for zinc in whole semen, fraction of split ejaculate and expressed prostatic fluid. Urology 1980;16:478-80.

43. Zaichick V, Tsyb A, Dunchik VN, Sviridova TV. Method for diagnostics of prostate diseases. Certificate of invention No 997281 (30.03.1981), Russia.

44. Zaichick V, Sviridova T, Zaichick S. Zinc concentration in human prostatic fluid: normal, chronic prostatitis, adenoma, and cancer. Int Urol Nephrol 1996;28:687-94.

45. Zaichick V. Applications of synthetic reference materials in the medical Radiological Research Centre. Fresenius J Anal Chem 1995;352:219-23.

46. Romics I, Bach D. Zn, Ca and Na levels in the prostatic secretion of patients with prostatic adenoma. Int Urol Nephrol 1991;23:45-9.

47. Gómes Y, Arocha F, Espinoza F, Fernandez D, Vásquez A, et al. Niveles de zinc en líquido prostático de pacientes con patologías de próstata. Invest Clin 2007;48:287-94.

48. Zaichick V, Sviridova T, Zaichick S. Zinc in human prostate gland: normal, hyperplastic and cancerous. Int Urol Nephrol 1997;29:565-74.

49. Kavanagh JP, Darby C. The interrelationships between acid phosphatase, aminopeptidase, diamine oxidase, citric acid, $\beta$-glucuronidase, $\mathrm{pH}$ and zinc in human prostate fluid. Int J Androl 1982;5:503-12.

50. Huggins C, Scott W, Heinen JH. Chemical composition of human semen and of the secretion of the prostate and seminal vesicles. Amer J Physiol 1942;136:467-73.

51. Zaichick V. Sampling, sample storage and preparation of biomaterials for INAA in clinical medicine, occupational and environmental health. Harmonization of health-related environmental measurements using nuclear and isotopic techniques. Vienna: IAEA; 1997. pp. 123-33.

52. Zaichick V, Zaichick S. A search for losses of chemical elements during freeze-drying of biological materials. J Radioanal Nucl Chem 1997;218:249-53.

53. Zaichick V. Losses of chemical elements in biological samples under the dry aching process. Trace Elements in Medicine 2004;5:17-22.

54. Zaichick S, Zaichick V. Method and portable facility for energy-dispersive X-ray fluorescent analysis of zinc content in needle-biopsy specimens of prostate. X-Ray Spectrom 2010;39:83-9.

55. Zaichick V, Zaichick S, Davydov G. Method and portable facility for measurement of trace element concentration in prostate fluid samples using radionuclide-induced energy-dispersive X-ray fluorescent analysis. Nucl Sci Tech 2016;27:1-8.

56. Moore RA, Miller ML, Mc Lellan A. The chemical composition of prostatic secretion in relation to benign hypertrophy of the prostate. J Urol 1941;46:132-7. 